\title{
An overview of alcohol screening and treatment programs in the Mexican health system
}

\author{
Marcela Tiburcio-Sainz ${ }^{*}$ Guillermina Natera-Rey \\ From International Network on Brief Interventions for Alcohol and Other Drugs (INEBRIA) Meeting 2013 \\ Rome, Italy. 18-20 September 2013
}

As in many other countries, the cost of alcohol abuse to the Mexican health system is considerable. The main contribution to disease burden is related to morbidity and mortality associated with liver cirrhosis, accidents, and violence, including homicide. Moreover, the largest share of alcohol-related problems is caused by those who drink heavily but do not fulfill dependence criteria; consequently, this group is not properly identified and do not get treatment, since the services available are aimed at treating people with dependence. The most frequently used services are those of 12-step groups, followed by alcohol detoxification. However, in Mexico there are several initiatives to test evidence-based programs for the prevention, detection, and treatment of alcohol abuse. The most significant initiatives are reviewed in this paper highlighting its relevance in the development and implementation of public policies in Mexico, such as a solid e-learning program to train health professionals on screening and treat alcohol abuse problems; research projects to test the effectiveness of various interventions, centered primarily on the management of problem drinkers; and brief intervention for the relatives of heavy drinkers, among others. It is hoped that these initiatives will have a significant impact on the prevention, screening, and treatment of alcohol abuse, but there are tasks that remain; for instance, we need a better understanding of the barriers to implementation. Greater efforts are needed to broaden the range of alcohol screening and treatment programs, improve their efficacy and costeffectiveness in different contexts, and encourage their adoption in the national health system.

Published: 4 September 2013

* Correspondence: tibsam@imp.edu.mx

National Institute of Psychiatry, Ramón de la Fuente Muñiz, Mexico City, Mexico

\section{Biomed Central}

๑ 2013 Tiburcio-Sainz and Natera-Rey; licensee BioMed Central Ltd. This is an Open Access article distributed under the terms of the Creative Commons Attribution License (http://creativecommons.org/licenses/by/2.0), which permits unrestricted use, distribution, and reproduction in any medium, provided the original work is properly cited.
doi:10.1186/1940-0640-8-S1-A77

Cite this article as: Tiburcio-Sainz and Natera-Rey: An overview of alcohol screening and treatment programs in the Mexican health system. Addiction Science \& Clinical Practice 2013 8(Suppl 1):A77.

Submit your next manuscript to BioMed Central and take full advantage of:

- Convenient online submission

- Thorough peer review

- No space constraints or color figure charges

- Immediate publication on acceptance

- Inclusion in PubMed, CAS, Scopus and Google Scholar

- Research which is freely available for redistribution 